\title{
RE-EXISTENCE OF ASTRONOMY BY THE ARCHIPELAGO SCHOLAR
}

\author{
Hosen \\ Institut Agama Islam Negeri Madura \\ hosen@iainmadura.ac.id
}

\section{Abstract}

The science of Islamic astronomy that develops in the Indonesian archipelago is quite diverse with various methods of approach and defined criteria. Along with the development of science and technology, the works of Indonesian archipelago mufti on science of Islamic astronomy seemed to have sunk without a trace. There are only a few that still exist and can be enjoyed by researchers and observers of science of Islamic astronomy. The rest has not been touched to be developed, let alone to be reconstructed. Reconstruction and reexamination of the science of Islamic astronomy by the previous mufti of Indonesian archipelago is very important for several things. As an appreciation for the services of the author, preserve and develope the scientific treasures. The writer examines this issue with the library research method. First, the writer traces the works of Indonesian mufti in an organized manner in each region. Second, classify these works according to the criteria of taqribī or tahq $\overline{1} q \overline{1}$. Third, reconstruct the works that belong to the taqribi category into the tahqīqi category. And fourthly, rewrite the works referred to as a form of preservation of scientific treasures in the field of Islamic astronomy. The results that will be obtained from the four stages above are, first; knowing how many previous works of Mufti of Indonesian archipelago in the field of Islamic astronomy in each region shows that Mufti of Indonesian archipelago had a high concern over the development of islamci astronomy at that time. Second; You will find a comparison of the number of works that belong to the taqribī and tahqīqi categories. Third; By reconstructing the works of the taqribī category into the tahqīqui category, it will further foster enthusiasm for carrying out scientific studies which are verybenefical in order to increase knowledge of Islamic astronomy. And fourth; The preservation of the scientific treasures of the Indonesian archipelago created by previous scholars of the Indonesian archipelago which can be used as a reference for future research.

Keyword: archipelago scholar, islamic astronomy, reconstruction 


\section{Abstrak}

Ilmu falak yang berkembang di nusantara cukup beragam dengan berbagai metode pendekatan dan kriteria. Seiring dengan perkembangan ilmu pengetahuan dan teknologi, karya-karya ulama nusantara tentang ilmu falak seakan tenggelam tanpa bekas. Hanya ada beberapa yang masih eksis dan dapat dinikmati oleh para peneliti dan pemerhati ilmu falak. Selebihnya belum tersentuh untuk dikembangkan apalagi direkonstruksi. Rekonstruksi dan penelahaan kembali terhadap ilmu falak karya ulama nusantara terdahulu sangat penting dilakukan untuk beberapa hal. Sebagai penghargaan atas jasa para mu'allif, melestarikan dan mengembangkan warisan khazanah keilmuan. Penulis mengkaji hal ini dengan metode library research. Pertama penulis menelusuri karya-karya ulama nusantara secara terorganisir dimasing-masing daerah. Kedua melakukan klasifikasi karya-karya tersebut sesuai dengan kriteria taqribī atau tahqqīqū. Ketiga merekonstruksi karya yang masuk kategori taqribī menjadi kategori tahqīqì. Dan keempat menulis kembali karya-karya dimaksud sebagai bentuk pelestarian khazanah keilmuan dibidang ilmu falak. Hasil yang akan diperoleh dalam melakukan empat tahapan diatas adalah, pertama; mengetahui seberapa banyak karyakarya terdahulu ulama nusantara dalam bidang ilmu falak di masing-masing daerah yang menunjukkan bahwa ulama nusantara memiliki perhatian yang tinggi terhadap berkembangnya ilmu falak pada saat itu. Kedua; akan ditemukan perbandingan jumlah dari karya tersebut yang termasuk kategori taqribì dan tahqqīqī. Ketiga; dengan merekonstruksi karya kategori taqribi menjadi kategori tahquīqi semakin menumbuhkan semangat untuk melakukan kajian-kajian keilmuan falak yang sangat bermanfaat dalam rangka meningkatkan pengetahuan. Dan keempat; lestarinya khzanah keilmuan falak hasil karya ulama nusantara terdahulu yang dapat dijadikan rujukan untuk penelitian-penelitian di masa yang akan datang.

Kata kunci: ulama nusantara, ilmu falak, rekonstruksi

\section{A. Introduction}

The science of Islamic astronomy that has developed until now is the result of the efforts of the previous mufti in studying and developing it. Along with the times, astronomy is also progressing. Likewise with the people who study it. To this day, there are educational institutions that specifically study astronomy from various perspectives.

In fact, the one who have not studied Islamic astronomy is the Islamic boarding schools (pesantren). Whereas, Islamic boarding schools is a source of astronomy in itself. Because most of the authors of the book of astronomy lived in Islamic boarding schools. It felt naïve if the Islamic boarding school itself is not studied Islamic astronomy. Especially those related to the issue of religious service. 
Such as the direction of the Qibla and prayer times. So what happens is the scarcity of future astronomers who teach their knowledge in Islamic boarding schools.

More than that, the works of mufti of Indonesian archipelago which became the embryo of the development of the Islamic astronomy in Indonesia more and more be drown. It has been replaced by contemporary methods which if be traced back, some of the sources still come from the research of previous mufti. With the increasing scarcity of works of previous mufti of Islamic astronomy, it is necessary to trace these works to be reprinted as a form of preservation. Besides, it is also a form introducting the history to the society, especially the successors who are active in the practice and development of Islamic astronomy in the future.

\section{B. Research Methods}

This research was conducted using the library research methode. The first step the writer takes is to organize works of Indonesians' mufti in each region. Then classify these works according to the criteria of taqribī or tahqīi $\overline{1}$. Furthermore, works that fall into the taqribī category are reconstructed into the tahqqīq $\overline{1}$ category. And finally rewriting the works referred to as a form of preservation of scientific treasures in the field of Islamic astronomy.

\section{Discussion and Results}

The tradition of the ancient people was traveling in order to explore as much knowledge as possible even if it means went to the other country. This indicates that equipping oneself with knowledge is a society's need for itself and for others. In addition, to become a preacher, it needs vast amount of knowledge and the regularity of his preaching is needed in accordance with the situation and conditions as well as the culture of the community he faces. Even though most of people in ancient times was to learn al-Qur ${ }^{`} a ̄ n$, hadis and fiqh, there were also those who studied Islamic astronomy (astronomy).

People who went on a journey to explore knowledge, some of them later became a mufti of their time. They extract knowledge directly from the source of the knowledge, Namely the Middle East, More specifically Makkah and Medina as sources of Islamic knowledge. A small number of them, besides studying al-Qur'ān, hadis and fiqh along others knowledge that covers them, also learn about 
astronomy or Islamic astronomy. The results of studying Islamic astronomy are then taught to their students, both those who live in Mecca and those who then return to their respective regions. Which in the XVII-XVIII centuries was better known as Malay-Indonesian. By returning home and the spreading of the muftis, it became an important milestone in the spreading and renewal of Islam in the Indonesian archipelago. ${ }^{1}$

\section{C.1. The work of Archipelago Ulama in Falak Science}

In the field of Islamic astronomy, there are many works of mufti of Indonesian archipelago that can be studied and developed today. It's just that up to this day, there are still very few institutions or individuals carrying out tracing and reconstruction of the manuscripts. This needs to be done massively in order to re-exist what has been written and transmitted by the earlier mufti. What Dr. H. Arwin Juli Rakhmadi Butar-Butar, MA with his book "Mengenal Karya-Karya Ilmu Falak Nusantara; Transmisi, Anotasi, Biografi" has opened the consept that it is very important to preserve the scientific treasures of earlier mufti. The author admits that the discussion in this book just covers little bit of Islamic astronmy compared to all the works that have been written in the past. ${ }^{2}$

In addition, in East Java, the reconstruction of the works of earlier mufti has begun. For example "Tashilul Wildan; Translated Sullamu Nayyiroin "written by Ali Mustofa. This book is a translation of the original book. This book aims' is to decipher the book of Sullamal-Nayyiroin which uses jumali number calculations. ${ }^{3}$ Currently, the reconstruction of other books written by an East Javanese Islamic astronomy muftis' is currently underway.

\footnotetext{
${ }^{1}$ Azyumardi Azra, Jaringan Ulama Timur Tengah $\mathcal{E}$ Kepulauan Nusantara Abad XVII $\mathcal{E}$ XVIII; Akar Pembaharuan Islam di Indonesia, Perenial (Depok: Prenadamedia Group, 2018), 347-48.

${ }^{2}$ H. Arwin Juli Rakhmadi Butar-Butar, Mengenal Karya-Karya Ilmu Falak Nusantara; Transmisi, Anotasi, Biografi, I (Yogyakarta: LKiS, 2017), vii.

${ }^{3}$ Ali Mustofa, Tashilul Wildan; Terjemah Sullamun Nayyiroin, 1st ed. (Ploso: Maktabah Musthofafwiyah, 2018), ii.
} 
Several mufti of Indonesian archipelago who have written the books of islamic astronomy in the past include, first; Shaykh Ahmad Khatib Minangkabau $^{4}$ wrote several books on Islamic astronomy in Arabic and Malay. Such as al-Qaul al-Mufīd Syarh Matla` al-Sa'īd (Arabic), al-Jawāhir alNaqiyyah fī al-A'māl al-Jaibiyyah (Arabic), Raựah al-Ḥussāb fī 'Ilm al-Ḥisāb (Arabic), 'Alamal-Ḥussāb fī' Ilm al-Ḥisāb (Malay), al-Bahjah al-Saniyyah fī alA'māl al-Jaibiyyah (Malay), al-Natījah al-Marḍiyyah fī Taḥqīq al- Sanah alSyamsyiyyah wa al-Qamariyyah and al-Nukhbah al-Bahiyyah (Malay).

Second; Shaykh Muhammad Djāmil Djambek who has the first name Inyiak, the son of Muhammad Shāleh. Born in Bukittinggi, West Sumatra on 13 Sya'ban $1280 \mathrm{H} / 4^{\text {th }}$ of January $1863 \mathrm{M}$. He studied astronomy in Makkah and became one of the famous astronomers in Makkah at that time. He teachs astronomy in Makkah to immigrants from the Indonesian archipelago. Shaykh Muḥammad Djāmil Djambek Returned to Minangkabau from studying in Makah in $1903 \mathrm{M}$ after 9 years living there since 1896 M and Died on 18 Șafar 1366 H / 30th December 1947 AD in Kampung Tangah Sawah Bukittinggi, West Sumatra. The falak books he wrote were Mukhtașar Maṭla ' al-Sa'īd fī Ḥisābāt al-Kawākib and Ḍiyā’ alNīrīn fīmā Yata'allaq bi al-Kawākib. This book was written on Thursday at Fajr in Makkah City on 25 Dulhijjah 1316 H. $^{5}$

Third; Habīb / Sayyid Usmān bin Abdillāh. Full name is Usimān bin 'Abdullāh bin' Āqil bin 'Umar bin' Āqil bin Syekh bin 'Abdurrahmānn bin' Äqil bin Aḥmad bin Yahyā bin Hasan bin 'Alī bin' Alwī bin Muhammad Maulā al-Dawīlah bin 'Alī bin' Alwībin Muhammad bin 'Al̄̄ bin Muhammad Ṣāḥib Mirbāt bin' Alī Khalā’ Qasam bin 'Alwī bin Muhammad bin' Alwī bin 'Ubaidillāh bin Aḥmad alMuhājir bin' İsā bin Muḥammad al-Naqūb bin 'Alī al'Uraid̄̄ bin Ja'far Șādiq bin

\footnotetext{
${ }^{4}$ From his father's lineage, he is fully named Shaykh Aḥmad Khațib bin Shaykh 'Abdul Lațîf bin Shaykh' Abdurrahmān bin Shaykh 'Abdullāh bin Shaykh'Abdul 'Azīz. Birth of Gadang City, Bukittinggi West Sumatra. The date, month and year of his birth are still debated. Some say he was born in 1860 A.D. 1276 H, others say he died in 1885 A.D. in 1334 A.D. 1915 A.D.See Ahmad Fauzi Ilyas, "Syekh Ahmad Khatib Minangkabau dan Polemik Tarerkat Naqsyabandiyah di Nusantara," Journal of Contemporary Islam and Muslim Societies 1, no. 1 (2017): 88, http://dx.doi.org/10.30821/jcims.v1i1.1008.

${ }^{5}$ Butar-Butar, Mengenal Karya-Karya Ilmu Falak Nusantara; Transmisi, Anotasi, Biografi, 106.
} 
Muhammad al-Bāqir bin 'Ali Zainal' Ābidīn bin Husein bin 'Alì bin Ab̄̄Ṭālib. Born in Pekojan Batavia (Betawi) on Sunday Pahing, 17 Rabiul Awwal 1238 H / 2th of December $1822 \mathrm{M}$, and died on Monday Pon, $19^{\text {th }}$ of January $1914 \mathrm{M}$ / 21 Safar $1332 \mathrm{H}$, and was buried at the Tanah Abang people cemetery, Jakarta. He is Known as the Mufti of Betawi. His work in the science of Islamic astronomy is Iqāọ al-Niyām fìmā Yata'allaq bi Ahillah wa al-Șiyām and Taḥrīr Aqwā al-Adillah fî Tahṣ̂̄ 'Ain al-Qiblah. ${ }^{6}$

Fourth; Shaykh Muḥammad Manșūr bin 'Abdul Ḥāmid Betawi. His full name is Muḥammad Manșūr bin 'Abdul Ḥāmid bin Muḥammad Damīrī bin Habīb bin' Abdul Muhịt (Pangeran Tjokrodjojo / Cakrajaya Tumenggung Mataram) al-Betawi. Born in the area of Kampung Sawah, Jembatan Lima, Tambora, West Jakarta on Monday Kliwon, December 31, 1878 M / 5 Muharram 1296 H. Better known by the nickname Tuan Guru Manșur. Died on Friday Wage, $12^{\text {th }}$ of May 1967 M / 2 Ṣafar 1387 H. $^{7}$ He wrote many books in the field of astronomy such as; Sullam al-Nayyirain fī Ma'rifah al-Ijtimā 'wa al-Kusufain, Mīzān al-I'tidāl fī Mas'alah Ikhtilāf al-Mațāli' wa Rukyah al-Hilāl, Khulāsah al-Jadwāl, Jadāwil al-Dawāir al-Falakiyyah , Arba 'Rasāil fī Mas`alah al-Hilāl, al-Rub' al-Mujayyab, Mukhtașar Ijtimā 'alNayyirain, al-Tażkirah al-Nafí'ah fī' Amal al-Șaum wa al-Fithr, Jadwāl alQiblah , Jadwāl Auqāt al-Ṣalah, Ta'līq 'Amal al-Ijtimā' wa al-Khusūf wa alKusūf. ${ }^{8}$

Fifth; Shaykh Aḥmad Daḥlān at-Tarmāsī as-Simarānī. Born in Termas, Pacitan, East Java in 1862 M and died in Semarang in 1911 M. His grave was lined up with Shaykh Sholeh Darat who was both his teacher and

\footnotetext{
${ }^{6}$ Azhari, Ensiklopedi Hisab Rukyat, 190.See alsoMuhyiddin Khazin, Kamus Ilmu Falak (Yogyakarta: Buana Pustaka, 2005), 104.Compare withMuhammad Noupal, "Kontroversi Tentang Sayyid Utsman bin Yahya (1822-1914) Sebagai Penasehat Snouck Hurgronje," in Annual International Conference on Islamic Studies (AICIS XII) (12 AICIS, Surabaya: UIN Sunan Ampel, 2012), 1370-91, https://core.ac.uk/download/pdf/34212359.pdf.

${ }^{7}$ Humaidi, "Guru Merah Putih: Ulama Betawi Dalam Dalam Perjuangan Kemerdekaan (1945-1950)" (Makalah, Seminar Nasional Sejarah ke 4 Jurusan Pendidikan Sejarah Universitas Negeri Padang, Padang), 431-34, accessed June 11, 2020, https://osf.io/hfkdy/download/?format=pdf.

${ }^{8}$ Azhari, Ensiklopedi Hisab Rukyat, 196.See alsoKhazin, Kamus Ilmu Falak, 110-11.Compare withButarButar, Mengenal Karya-Karya Ilmu Falak Nusantara; Transmisi, Anotasi, Biografi, 108-19.
} 
father-in-law at the Bergota Cemetery complex in Semarang. His full name was Aḥmad Dạ̣lān bin 'Abdullāh bin' Abdul Mannān bin Demang Dipomenggolo I bin Ketok Jenggot (Punggawa Keraton Surakarta) at-Tarmāsī as-Simarān̄i. Named as At-Tarmāsī because he was born in Termas, Pacitan, and as-Simarān̄ because he was domiciled in Seramang until the end of his life. His work in the field of Islamic astronomy is Tażkirah al-Ikhwān fī Ba'ḍ Tawārīkh A'māl al-Falakiyyah bi Semarang (completed in 1901 M) and Natījah al-Miqāt (completed in 1903 M) and Bulūg al-Waṭar (completed written on 27 Żulqa'dah 1320 H). ${ }^{9}$

Sixth; Shaykh Iḥsān Jampes. His childhood name was Bakri. Born in Jampes, Kediri, East Java in 1901 AD. His full name is Bakri (Ihsan) bin KH. Dahlan bin KH. Sholeh came from Bogor and lived in Kediri. Died on Monday Pahing, 25 $5^{\text {th }}$ Zulhijjah $1371 \mathrm{H} / 16^{\text {th }}$ September $1952 \mathrm{H}$ and was buried in Kediri, East Java. His works in Islamic astronomy field is Tașrịh al'Ibārāt which is an explanation (Syarḥ) of the book Natījah al-Miqātkarangan Shaykh Aḥmad Daḥlān at-Tarmāsī written in 1903 M. ${ }^{10}$

Seventh; Shaykh 'Abdul Jalīl Hamid Kudus. His Full name is AbūḤamdān 'Abdul Jalīl bin' Abdul Ḥāmid. Born in Bulumanis Kidul, Margoyoso Tayu, Pati, Central Java on Sunday Kliwon, $2^{\text {nd }}$ of July 1905 M / 28 Rabīul Ākhir 1323 H. He died in Makkah al-Mukarramah on Saturday Pon, 16 Żulqa'dah $1394 \mathrm{H} / 30^{\text {th }}$ of November 1974 M. His work in the field of islamcic astronomy is Fatḥ al-Rauf al-Mannānli 'Amal al-Kusūf bi Zaij alDakhlān. Until now, this book has become one of the literatures in

\footnotetext{
${ }^{9}$ M. Rikza Chamami, “KH. Ahmad Dahlan: Ahli Falak Nusantara,” NU Online, Agustus 2016, https://www.nu.or.id/post/read/70710/kh-ahmad-dahlanahli-falak-nusantara.

${ }^{10}$ Arifatus Sa'adah, "Ngudud dan Ngipok Menurut Syaikh Ihsan Muhammad Dahlan al-Jampesi Kediri” (Skripsi, Surabaya, UIN Sunan Ampel, 2016), 18-22, http://digilib.uinsby.ac.id/4734/.See alsoMoch. Arifin and Moh. Asif, "Penafsiran al-Qur’ān KH. Iṇsān Jampes; Studi Intertekstualitas Dalam Kitab Sirāj alTāālibīn,” Al-Itqan; Jurnal Studi al-Qur`an 1, no. 2 (July 2015), https://www.academia.edu/39944231/PENAFSIRAN_AL_QURAN_KH_IHSAN_JAMPES_Moh_Arifin201 90727_18551_vbia9k.Compare withR. Arid Hidayat, "Kontroversi Hukum Rokok Dalam Kitab Irsyād alIkhwān Karya Syeikh Iḥsān Muḥammad Daḥlān,” International Journal Ihya `Ulum Al-Din 17, no. 2 (2015): 189-208.See alsoA. Ginanjar Sya'ban, "Sirajut Thalibin, Syarah Kiai Ihsan Jampes atas Kitab Tasawuf Imam al-Ghazali,” NU Online, April 6, 2017, https://www.nu.or.id/post/read/76762/sirajut-thalibin-syarah-kiaiihsan-jampes-atas-kitab-tasawuf-imam-al-ghazali.
} 
determining the beginning of Islamic month in Indonesia. Apart from being an expert in astronomy, he held a positions including; Chairman of the Holy Religious Court, Special Assistant to the Prime Minister in Jakarta, Members of the DPR / MPR Center representatives of the NU faction of Ulama, Chairman of the PBNU Lajnah Falakiyah, and members of the Rukyat Rukyat Body of the Indonesian Ministry of Religion. ${ }^{11}$

Eighth; KH. Muhammad Wardan Diponingrat bin Kyai Muhammad Sangidu. Born in Kauman Yogyakarta on Friday Pahing, $20^{\text {th }}$ of Jumadil Awal $1329 \mathrm{H} / 19^{\text {th }}$ of May 1911 M. the forefatherr of hisab wujudul hilal used by Muhammadiyah to date. Died on Sunday Pahing, 19 Rajab $1411 \mathrm{H} /$ 3th of February $1991 \mathrm{H}$. His writings in the field of Islamic astronomy are Hisab Urfi dan Hakiki, Kitab Ilmu Falak dan Hisab, and 'Umdat al-Hasib. ${ }^{12}$ Ninth; Syaikh Yūnus 'Abdullāh Kediri. ${ }^{13}$ His essays are the books Risālah al-Qamarain and Tashīl al-Mis̄āl wa al-Aqwāl li 'Amal al-Hilāl. Tenth; KH. Muḥammad Hasan Asy'ari. Born on Bawean Island, Gresik Regency, East Java in the 1980s. Almost no one knows his biography because much of his life was spent in the Middle East. Then he lived in Pasuruan until the end of his life. No one know the validity of his death. It was around 1918-1921 M. His body was buried in Pondok Pesantrern Besok, Pasuruan. His books are Muntahā Natāij al-Aqwāl dan Jadwal al-Auqāt.

Eleventh; Shaykh Tahir Jalāluddīn. Born in Koto Tuo Ampat / Cangking, Bukittinggi West Sumatra on $7^{\text {th }}$ of December, $1869 \mathrm{M} / 4$ Ramaḍan 1286 H. His full name is MuhammadṬahir bin Muhammad bin Jalāluddīn Aḥmad bin 'Abdullāh. He died in Kuala Kangsar, Perak, Malaysia on 22 Rabīul Awwal $1376 \mathrm{H} / 26^{\text {th }}$ of October 1956 Mat the age of 87 years. His essays in the field of falak are Natījah al'Umr,Nukhbah al-Taqrīrāt fïHisāa al-Auqāt wa Simtu al-Qiblah bi al-Lugāritmiyyah, Jadwāal Pātī Kiraan pada Menentukan Waktu yang Lima dan Hala Kiblat dengan Logaritma, dan al-Qiblah

\footnotetext{
${ }^{11}$ Azhari, Ensiklopedi Hisab Rukyat, 2-3.See alsoButar-Butar, Mengenal Karya-Karya Ilmu Falak Nusantara; Transmisi, Anotasi, Biografi, 136.

${ }^{12}$ Azhari, Ensiklopedi Hisab Rukyat, 235.

${ }^{13}$ The author has not found his biography.
} 
fī al-Nuṣūs Ulamā’ al-Syāfi'iyyah fīmā Yata'allaq bi Istiqbāl al-Qiblah al-Syar'iyyah Manqūlah min Ummahāt Kutub al-Mażhab. ${ }^{14}$

Twelfth; Shaykh Muhammad Ma'ṣūm bin 'Alī. His full name is Muḥammad Ma'ṣūm bin 'Alī bin' Abdul Muḥȳ̄ Maskumambang. Born in 1305 H / 1887 AD in Maskumambang Village, Sedayu District, Gresik. Studying with Shaykh Muḥammad Ḥāsyim Asy'ārī at Pondok Pesantren Tebuireng Jombang. After Tebuireng, he studied in Makkah. After returning from Makkah, he was made to be a son-in-law of Shaykh Muammad Ḥāsyim Asy'ārī, and started the Seblak Islamic Boarding School, not far from his father-in-law's school. Died on 24 Ramadan $1351 \mathrm{H} / 8^{\text {th }}$ of January $1933 \mathrm{M}$ at a young age, 46 years. His books in the field of Islamic astronomy are alDurus al-Falakiyyah and Badī'ah al-Mis̄āl fī Ḥisāb al-Sinīn wa al-Hilāl. ${ }^{15}$

Thirteenth; Shaykh Muḥammad Mukhtār bin 'Atarid al-Bogorī. Born in Bogor, West Java on Thursday 14 Sya'bān $1278 \mathrm{H} / 14^{\text {th }}$ of February $1862 \mathrm{M}$, and died in Makkah on Sunday, 17 Șafar $1349 \mathrm{H} / 13^{\text {th }}$ of July 1930 M His real name was Raden Muhammad Mukhtār bin 'Atarid (Raden Natanagara). His contribution to the science of Islamic astronomy is the book Taqrīb al-Maqșad fī al-'Amal bi al-Rub 'al-Mujayyab. ${ }^{16}$

Fourteenth; Shaykh Zubair 'Umar al-Jailānī. Born in Padangan Village, Padangan District, Bojonegoro Regency, East Java on September $16^{\text {th }}$, 1908 M. He died on $10^{\text {th }}$ of September, 1990 M / 24 Jumādil Awal 1411 H in Surakarta. During his lifetime he served as a Judge at the Salatiga District Court, Chairman of the Surakarta High Islamic Court and Rector of IAIN Walisongo Semarang. His contributions to the science of astronomy are his writings that still exist today, namely; al-Khulasah al-Wafiyyah, works (d. 1411 $\mathrm{H} / 1990 \mathrm{AD}){ }^{17}$

\footnotetext{
${ }^{14}$ Butar-Butar, Mengenal Karya-Karya Ilmu Falak Nusantara; Transmisi, Anotasi, Biografi, 33.Compare withAzhari, Ensiklopedi Hisab Rukyat, 205.

${ }^{15}$ Butar-Butar, Mengenal Karya-Karya Ilmu Falak Nusantara; Transmisi, Anotasi, Biografi, 86.

${ }^{16}$ Azhari, Ensiklopedi Hisab Rukyat, 204-5.

${ }^{17}$ Ahmad Izzuddin, "Syaikh Zubair Umar al-Jailany (w. 1411 H/1990 M) dalam Sejarah Hisab di Indonesia,” Al-Marshad; Jurnal Astronomi Islam dan Ilmu-Ilmu Berkaitan 2, no. 2 (2016): 94-105,
} 
Fifteenth; Shaykh Aḥmad Saleḥ Maḥmūd Jauhārī Cirebon.al-Maksūf. ${ }^{18}$

Sixteenth; Sheikh Muhammad Zubair 'Abdul Karīm. Born in Sampurnan Village, Bungah Gresik District, on Monday Kliwon 13 June 1921 M / 7 Shawwal 1339 H. His Full name is Muhammad Zubair bin KH. 'Abdul Karīm bin KH. Muhammad Sholeh Śani bin Nyai Rosiyah bint KH. Hārun bin KH. Qomaruddīn. During his lifetime, he was active in the NU falakiyah institution, both at the regional and central levels. One of his contributions is the book Ittifāq Żat al-Bain fī Ḥisāb al-Hilāl wa al-Kusūfain which was written in 1980. He died on Saturday Pon, 4 Żulhijjah $1442 \mathrm{H} / 16^{\text {th }}$ of February $2002 \mathrm{M}$, at the age of 81 years. ${ }^{19}$

Seventeenth; Shaykh Saadoe'ddin Djambek. Born in Bukittinggi, West Sumatra on March 24 $4^{\text {th }}, 1911$ M / 29 Rabiul Awal 1329 H, and died in Jakarta on 11 Żulhijjah $1397 \mathrm{H}$ / November 22th, 1977 M. He is the son of Sheikh Muhammad Djāmil Djambek and has the title Datuk Sampono Radjo. His grandfather was Muhammad Saleh Datuk Maleka, head of the Kurai nagari. He was one of the pioneers of the establishment of the Hisab and Rukyat Agency of the Ministry of Religion of the Republic of Indonesia and became the first chairman. His writings have become a reference and inspiration for observers of Islamic astronomy today. His works in the field of astronomy are also numerous, such as; Waktu dan Djadwal Pendjelasan Populer Mengenai Perdjalanan Bumi, Bulan dan Matahari, Almanak Djamiliyah, Perbandingan Tarich, Pedoman Waktu Sholat Sepandjang Masa, Sholat dan Puasa di Daerah Kutub, and Hisab Awal Bulan Qamariyah. ${ }^{20}$

Eighteenth; Shaykh 'Abd al-Raūf al-Fanșūrī. Allegedly born in Singkel, Aceh in $1024 \mathrm{H} / 1615 \mathrm{AD}$ and died in Kuala Aceh in $1105 \mathrm{H} / 1693 \mathrm{AD}$ has the full name Amīnuddīn 'Abdul Raūf bin' Al̄̄ al-Jāwī Fansur al-Singkili. Many of his essays

https://doi.org/10.30596/jam.v2i2.2532.AndButar-Butar, Mengenal Karya-Karya Ilmu Falak Nusantara; Transmisi, Anotasi, Biografi, 128-29.

${ }^{18}$ The author has not found his biography.

${ }^{19}$ M. Faishol Amin, "Studi Analisis Pembaruan Perhitungan Awal Bulan Kamariah Dalam Kitab Ittifaq Dzatil Bain Karya KH. Moh. Zubair Abdul Karim” (Skripsi, Semarang, UIN Walisongo, 2016), 42-46, http://eprints.walisongo.ac.id/5770/1/122111071.pdf.

${ }^{20}$ Azhari, Ensiklopedi Hisab Rukyat, 185-87.Compare withOman Fathurohman SW, "Saadoe'ddin Djambek Dan Hisab Awal Bulannya," in Bunga Rampai Hisab Rukyat dan Perbedaannya (Jakarta: Departemen Agama RI, 2018), 92-123, http://digilib.uin-suka.ac.id/id/eprint/29754. 
are in the fields of hadī̇s, fiqh and tașawwuf. While only one book of falak was found with the title Risālah al-Shaykh 'Abd al-Raūf fĩ al-Taqwīm. ${ }^{21}$

Nineteenth; Shaykh Muḥammad Arsyād al-Banjārī. His full name is Muḥammad Arsyād bin 'Abdullāh bin' Abdurrasȳ̄e bin 'Abdullāh al-Banjarī al'Idrūsī. The figure who has the posthumous title Datuk Kalampayan was born in Lok Gabang Village, Martapura, South Kalimantan, on Thursday $19^{\text {th }}$ of March $1710 \mathrm{M}$ / 15 Safar 1122 H. He died at the age of 105 years, precisely on Tuesday, October $13^{\text {th }}, 1812 \mathrm{M}$. / 6 Shawwal $1227 \mathrm{H}^{22}$ His contributions in the field of islamic astronomy are in the form of writing, namely; Risālah 'Ilm al-Falak, Risālah al-Qiblah and Kar Dunyā and Khat al-Istiwā’ ${ }^{23}$

Twentieth; Shaykh Hasan Ma'ṣum. His full name is Hasanuddin bin Muḥammad Ma'ṣum bin Abū Bakar. Born on Saturday 17 Muharram 1301 H / 1882 M, in Labuhan Deli, East Sumatra And Died on Thursday 24 Shawwal 1355 H $/ 7^{\text {th }}$ of January 1937 M. His essay in the science of falah is Natijah Abadiyah. ${ }^{24}$

Twenty-first; Shaykh Muḥammad Faqīh bin 'Abd al-Jabbār alMaskumambāngi. The full name is Muhammad Faqīh bin KH. 'Abdul Djabbar bin Kadiyun bin Wirosari (Kuda Leksono) bin Siman bin Sarimah binti Ongkoyudan bin' Abdullah bin 'Abdul Djabbar I (Pangeran Selarong) bin Pangeran Benowo bin Jaka Tingkir (Pengeran Pajang). Born in $1857 \mathrm{M}$ at the Maskumambang Islamic Boarding School, Sembungan Kidul Village, Dukun District, Gresik Regency. And died in $1353 \mathrm{H} / 1937 \mathrm{M}$ at the age of 80 years. His work in astronomy is al-

\footnotetext{
${ }^{21}$ Butar-Butar, Mengenal Karya-Karya Ilmu Falak Nusantara; Transmisi, Anotasi, Biografi, 67.See alsoMohammad Imron Rosyadi, "Pemikiran Hadis Abdurrauf As-Singkili Dalam Kitab Mawa'izat Al-Badi'ah," Diroyah; Jurnal Ilmu Hadis 2, no. 1 (September 2016): 55-62.Compare with Muhammad Rozali, "Kontribusi Syaikh Hasan Maksum dalam Bidang Pendidikan di Sumatera Utara,” JUSPI: Jurnal Sejarah Peradaban Islam 1, no. 2 (2017): 277-87.

${ }^{22}$ Usman Husnan, Moch. Muhairil Yusuf, and Badrus Sholeh, Guru Orang-Orang Pesantren, ed. Mohammad Achyat Ahmad, 1st ed. (Pasuruan: Pustaka Sidogiri, 2013), 386-89.

${ }^{23}$ Butar-Butar, Mengenal Karya-Karya Ilmu Falak Nusantara; Transmisi, Anotasi, Biografi, 70.

${ }^{24}$ Arwin Juli Rakhmadi Butar-Butar, "Kajian Ilmu Falak Di Indonesia: Kontribusi Syekh Hasan Maksum Dalam Bidang Ilmu Falak," Journal of Contemporary Islam and Muslim Societies 1, no. 1 (June 2017): 113-34.
} 
Manẓūmah al-Daliyyah fī Awāil al-Asyhur al-Qamariyyah 'Alā Ṭarīqah al-Fuqahā' alSunniyyah Allatī Tanbanī' Alā al-Ahādīì al-Nabawiyyah. ${ }^{25}$

The twenty-second; Shaykh Hasan bin Yahyā Jambi. His name is Hasan bin Anang Yahyāa and more known as Ḥasan bin Yahyā. Born in the village of Tengah, in Jambi in $1895 \mathrm{M}$, and died in $1940 \mathrm{M}$ at the age of 45 years. Only one of his works is in the field of astronomy, namely; Nail al-Maṭlūb fī A'māl al-Juyūb. ${ }^{26}$

Twenty third; Shaykh Muḥammad Yāsīn bin 'sā al-Fādānī. Born in Misfalah, Makkah, on Tuesday 27 Sya'bān 1335 H / 1916 M And also died in Makkah on Friday night 28 Żulhijjah 1410 H / 1990 M, he was buried in Ma'la cemetery. In a note, he composed as many as 36 books related to Islamic astronomy. Not a small amount of number. There are only a few book that have been listed, there are; Syaraḥ Śmarāt al-Wasīlah al-Musammā bi al-Mawāhib al-Jazīlah fī Azhār alKhamīlah,Janiyyuś Śamar Syarh Manẓūmah Manāzil al-Qamar, Ṭabaqāt 'Ulamā’ al-Falak wa al-Mīqāt, al-Khamīlah Syaraḥ Mutawassiṭ 'Alāíamarāt al-Wasīlah, al-Fawāid alJamīlah Syarah Kabīr 'Alāísamarāt al-Wasīlah, Mukhtaṣar al-Muhażżab fī Istikhrāj alAuqāt wa al-Qiblah bi al-Rubu' al-Mujayyab, al-Kitāb al-Kabīr fī 'Ilm al-Falak wa al-Mīqāt, Taqrīb al-Maslak li man Arāda 'Ilm al-Falak,dan al-Kaukab al-Anwār fī Asmā' al-Nujūm wa 'Iddah al-Șuwar. ${ }^{27}$

Twenty-fourth; Teungku Muhammad 'Alī Irsyād. Also known as Abu Teupi Teungku Muhammad 'Al̄̄ Irsyād. Born in Kayee Jatoe (Teupin Raya), Glumpang Tiga, Pidie, Aceh, in $1921 \mathrm{M}^{28}$, however there are other notes, that he was born in

\footnotetext{
${ }^{25}$ Faridah Hidayatul Mahiroh, "Perbandingan Pemikiran KH. Muhammad Faqih Maskumambang dan KH. Ammar Faqih Maskumambang Dalam Merespon Gerakan Wahabi Tahun 1922-1961 M" (Skripsi, Surabaya, UIN Sunan Ampel, 2019), 21-39, http://digilib.uinsby.ac.id/31737/.

${ }^{26}$ Butar-Butar, Mengenal Karya-Karya Ilmu Falak Nusantara; Transmisi, Anotasi, Biografi, 101-2.

${ }^{27}$ Husnan, Yusuf, and Sholeh, Guru Orang-Orang Pesantren, 420-22.Compare withNur Hidayatullah, "Jaringan Ulama Falak Nusantara (Studi Geonologi Keilmuan Falak Syekh Muhammad Yasin Al-Fadani)," AlAfaq; Jurnal Ilmu Falak dan Astronomi 1, no. 1 (2019): 35-66.

${ }^{28}$ Butar-Butar, Mengenal Karya-Karya Ilmu Falak Nusantara; Transmisi, Anotasi, Biografi, 140.Compare with Muhammad Rizal and Muhammad Iqbal, "Dayah and Meunasah: Abu Teupin Raya Is the Reformer of Islamic Education in Aceh," Jurnal Pendidikan Islam 7, no. 1 (June 2018): 185-208, https://doi.org/10.14421/jpi.2018.71.185-207.
} 
1915 and died in 2003 M $^{29}$. His essay in Islamic astronomy is al-Dahwah al- Kubrā fī 'Ilm al-Mīqāt and Taqwīm al-Hijri.

Twenty-fifth; KḤ. Noor Aḥmad Șadiq Saryani Jepara. Born on Wednesday Pahing 19 Rajab $1351 \mathrm{H} / 14^{\text {th }}$ of December $1932 \mathrm{M}$ in Jepara, Central Java. He also passed away on Wednesday Kliwon 30 Rajab $1433 \mathrm{H} / 20^{\text {th }}$ of June $2012 \mathrm{M}$ in his homeland. His expertise in the field of Islamic astronomy is not to be doubt. His works that become references for many observers of falak in Indonesia is Nūr alAnwār min Munjukā al-Aqwāl fī Ma'rifah Ḥisāb al-Sinīn wa al-Hilāl wa al-Khusūf wa al-Kusūf 'Alā al-Haqīīi bi al-Tahqīqū bi al-Rașd al-Jadīd, Syawāriq al-Anwār and Shams al-Hilāl.

Twenty-sixth; KH. 'Abdul Faqīh Demak. al-Kutub al-Falakiyyah. ${ }^{30}$

Twenty-seventh; KH. 'Abdul Fatah Gresik. Mużakarah al-Hisāb. Twenty-eight; KH. Muhammad Khalil Gresik. Wasīlah al-Ṭullāb.

Twenty-ninth; KH. Ahmad Dahlan Yogyakarta. His given name is Muhammad Darwis, was born in Kampung Kauman Yogyakata on first of August, $1868 \mathrm{M} / 1285 \mathrm{H}$, and died on 23th of February $1923 \mathrm{M} / 7$ Rajab $1342 \mathrm{H}$. He is the Founder of Muhammadiyah organization and famous for his renewal of the direction of the Yogyakarta Agung Mosque Qibla. He was using hisab calculations in calculating the beginning of fasting and Eid when it was still dominated by the Aboge system. So he wrote his work entitled Hisāb Ijtimā 'as a guide for his organization and the palace. ${ }^{31}$

Thirtieth; KH. Ahmad Badawi bin KH. Aḥmad Faqih. Born in Kampung Kauman Yogyakarta on February 5, 1902 AD / 25 Shawwal 1319 H, and died on Friday Pahing 25 April 1969 M / 8 Șafar 1389 H, at the age of 67 years. Chairman

\footnotetext{
${ }^{29}$ Rejal Afriansyah, "Biografi Tengku Haji Muhammad Ali Irsyad (Abu Teupin Raya 1915-2003)" (Skripsi, Darussalam-Banda Aceh, Universitas Syiah Kuala, 2017), iii, https://etd.unsyiah.ac.id/baca/index.php?id=47073\&page=10.

${ }^{30}$ The author did not find his biography. This name is listed in Kamus Ilmu Falak book without any complete information.SeeKhazin, Kamus Ilmu Falak, 95.

${ }^{31}$ Azhari, Ensiklopedi Hisab Rukyat, 13-14.Compare withH. Rohmat, "Penentuan Awal Bulan Qamariyah Menurut Muhammadiyah," Ijtimaiyya; Jurnal Pengembangan Masyarakat 7, no. 1 (February 2014): $127-45$.
} 
of PP. Muhammadiyah 1962-1965 period. His contribution to the science of islamic astronomy was a book written named Hisab Hakiki. ${ }^{32}$

Thirty-first; KH. Anwar Katsir, a religious leader in Malang ${ }^{33}$. He teachs Islamic astronomy to the society and writes the book Matahari dan Bulan dengan Hisab.

Thirty-two; Dawam Solo with his Taqwīm al-Nayyirain.

Thirty-three; KH. Ahmad Qasim, with his creation Tuhfah al-Ikhwān.

Thirty-four; KH. Mawardi Semarang, authored the book Risālah al-Nayyirain.

Thirty-five; KH. Muhammad Amin Surakarta, his book is Jadāwil al-Falakiyyah.

Thirty-six; KH. Nawawi Bogor, has the book falaknyaal-Mujastā.

Thirty-seven; KH. Ali Wardi, wrote the book falak Taqwīm al-Nayyirain.

Thirty-eight; KH. Qusyairi Pasuruan, authored a book on the science of falak Jadāwil al-Falakiyyah.

Thirty-nine; KH. Ramli Hasan Gresik, wrote the book science of falak Risālah alFalakiyyah.

Forty; KH. Ridwan Sedayu-Gersik, his book is Taqrīb al-Maqșad. ${ }^{34}$

Forty-first; Drs. H. Abdul Razak, SH., Was born in Cepu, Central Java on $5^{\text {th }}$ of September 1938 H / 10 Rajab 1357 H, and died on Wednesday, $17^{\text {th }}$ of May 2000 M / 13 Safar $1421 \mathrm{H}$. He was appointed as a member of the Hisab and Rukyat Agency. RI Department of Religion. One of his works in the field of astronomy is Sistem Perhitungan/Penentuan Waktu Sholat Seluruh Indonesia. ${ }^{35}$

Forty-two; KH. A. Ghazali. Born in Bojong Herang, Cianjur, West Java, on Thursday Wage, $08^{\text {th }}$ of August 1935 M / 08 Jumadal Ula 1354 H. He started his education at the school of citizen (equal with elementary school) in 1942-1947 M in Bojong Herang. He is a Members of the Hisab and Rukyat Board Ministry of Religion of the Republic of Indonesia (1983-2003 M), Chairman of the Regional Leadership of the Islamic Union for the II region Bogor (1989-1992 M), Member of the Hisbah Council of the Central Executive of the Islamic Union (1990-2003 M),

\footnotetext{
${ }^{32}$ Azhari, Ensiklopedi Hisab Rukyat, 12-13.

${ }^{33}$ The author did not find his biography.

${ }^{34}$ The biographies of these authors were not found. Only written globally in Kamus Ilmu Falak book.

${ }^{35}$ Azhari, Ensiklopedi Hisab Rukyat, 6-7.
} 
Member of Thaaifah Mutafaqqihina Fiddien (TMD) Risalah ( 1992-2003 M), Coleader of the Regional Leadership of the Islamic Association of Cianjur Regency (1992-2003 M), and Chairman of the Hisab and Rukyat Council of the Islamic Union Center (1993-2003 M). One of his writings in the science of Islamic astronomy is Mabādi 'al-Falakiyyah. ${ }^{36}$

Forty-third; Shaykh Muḥammad Șālih al-Fațānī. Historically, he was born on a ship in Sabang, northern Aceh. His full name is Muhammad Șālih bin Syaikh Abdurrahmān Gudang bin Muhammad Șālih bin Ismāil al-Fațānī. In 1948, Shaykh Muhammad Șālih was appointed as an employee of the Indonesian Ministry of Religion and served in Palembang until the end of his life. His death date is still undetermined. The books written in the field of Islamic astronomy are Alamanak Arabi dan Masehi Buat Selama-lamanya dan Risalah Durar al-Azman pada Mengirakan Pangkal Tiap-tiap Tahun dan Bulan. ${ }^{37}$

Forty-fourth; KH. Salamun Ibrahim. Born in Paciran, Lamongan on Tuesday Wage, 3d of may May 1921 M / 24 Sya'bān 1339 H. Died Wednesday Wage, $15^{\text {th }}$ of June 2005 M / 7 Jumadal Ula 1426 H. KH. Salamun Ibrahim Learned the science of Islamic astronomy from KH. Mahfūz Anwār. Written the book Ilmu Falak. ${ }^{38}$ Forty-five; Shaykh 'Abbas Kutakarang Aceh. Sirāj al-Ẓalām fī Ma'rifah al-Sa'd wa al-Nahāâs fī al-Syahr wa al-Ayyām and Tāj al-Muluk. ${ }^{39}$

The forty-sixth; Shaykh Aḥmad al-Fātānī. The full name is Wan Aḥmad bin Wan Muḥammad Zainal 'Ābidīn bin Datuk Commander of the Rich Sheikh Haji Wan Muṣṭafā bi Wan Muḥammad bin Wan Muḥammad Zainal' Ābidīn (Fāqih Wan Mūsā al-Jambuīal-Sanawī al-Fātihnī) bin Wan Mu Alammad 'Alālān̄̄) bin Wan Muḥammad' Șālānī) al-Masyhūr al-Lāqihī. Born in Jambu Village, Jerim Patani on 5 Sya'bān $1272 \mathrm{H} / 10^{\text {th }}$ of April $1856 \mathrm{M}$ And died on the night of

\footnotetext{
${ }^{36}$ Utsman BN, "Biografi KH. A. Ghazaly Ahli Hisab Persatuan Islam,” Blognya Orang Islam (blog), accessed January 28, 2019, https://muslimnurdin.wordpress.com/2010/10/23/biografi-kh-a-ghazaly-ahli-hisabpersatuan-islam/.

${ }^{37}$ Azhari, Ensiklopedi Hisab Rukyat, 154-55. Bandingkan dengan Wan Mohd. Shaghir Abdullah, "Kyai Muhammad Shalih al-Fathani - Ahli Falak Nusantara," Ulama Nusantara (blog), accessed June 14, 2020, http://ulama-nusantara.blogspot.com/2006/11/kiyai-muhammad-shalih-al-fathani-ahli.html.

${ }^{38}$ Azhari, Ensiklopedi Hisab Rukyat, 188.

${ }^{39}$ Hasna Tuddar Putri, "Pemikiran Syekh Abbas Kutakarang tentang Hisab Penentuan Awal Bulan Hijriyah,” n.d., 4, http://eprints.walisongo.ac.id/41/1/Hasna_Tuddar_Putri_Tesis_Sinopsis.pdf.
} 
Wednesday, 11 Żulhijjah $1325 \mathrm{H}$ simultaneously $14^{\text {th }}$ of January $1908 \mathrm{M}$ exactly 100 years he passed away according to Islamic calerndar. His work in Islamic astronomy are Taḥqīq Matn al-Syakhawiyyah fì 'Ilm al-Ḥisāb and Taḥqīq Wasīlah alṬullāb li Ma'rifah A'māl al-Lail wa al-Nahār bi Ṭarīqah al-Hisāb. ${ }^{40}$

Forty-seventh; KH. Misbah Malang, wrote the works of Risālah al-Falakiyyah.

Forty-eight; KH. 'Abdul Nașir, his essay Kitabal-Aqțār.

Forty-nine; Shaykh Nawawī bin Yūnus. Named Muhammad Nawawi bin Shaykh Muhammad Yunus bin 'Abdullah bin' Umar. Born on Saturday Legi, $28^{\text {th }}$ of January 1928 AD / 5 Sya'bān 1346 H, and died on Monday Pahing, 7 Rajab 1425 H / 23th of August 2004 M. His work in the field of falak including Wasīlah al-Mubtadī̄n fī Tarjamah Risālah al-Qamarain fī Ijtimā’ al-Nayyirain and Tashōl al-Mis̄āl. ${ }^{41}$

Fiftieth; KH. Gazālī Rembang. Born in Gandrirojo Village, Sedan District, Rembang Regency, Central Java, in 1921 M. His full name is KH. Gazālì bin Mas'ūd bin Irshad bin Syarīf. Studying astronomy in Kediri, East Java from KH. Yūnus bin 'Abdullāh. He passed away on Thursday Pahing, 17 th $^{\text {th }}$ April 1997 M / 9 Żulhijjah $1417 \mathrm{H}$, at the age of 76 years. Authored several books of astronomy, such as; Kasyf al-Jilbāb fi al-Ijtimā 'bi Aqșār al-Hisāb' Alā Tarīqat al-Shaykh Yūnus bin 'Abdullāh alQadīrī (completed on Wednesday Kliwon, 5 Sya'bān 1408 H / 23th of March 1988 M), Bulūg al -Wațar fi al-'Amal bi al-Qamar, and Risālah fi al-Amal bi al-Rub 'alMujayyab. ${ }^{42}$

Fifty-one; KH. Hasan Baṣrī Gresik. ${ }^{43}$ Risālah al-Hisābiyyah.

For now, the data the writer get is there are 51 authors of books / books in the field of Islamic astronomy, all of whom are the mufti of Indonesian archipelago.

\footnotetext{
${ }^{40}$ Diyak Ulrahman bin Mat Saad and Muhammad Faiz Mukmin bin Abdul Mutalib, "Sumbangan Shaykh Ahmad Al-Fathani (1856-1908) Terhadap Ilmu Nahu," n.d., http://conference.kuis.edu.my/pantumn2017/images/prosiding/Diyak.pdf.Compare withChe Ku Nur Saliehah binti Che Ku Hassan, "Sheikh Ahmad Fatani \& His Contribution in (Fiqh) Islamic Jurisprudence Writing," International Journal of Academic Rersearch in Bussiness and Social Sciences 7, no. 4 (2017): 186-93.

${ }^{41}$ Unggul Suryo Ardi, "Studi Analisis Hisab Awal Bulan Kamariah Dalam Kitab Wasilatu AlMubtadi'in Fi Tarjamati Risalati Al-Qamarain Fi Ijtima'i Al-Nayyirain Karya Syekh Muhammad Nawawi Yunus" (Skripsi, Semarang, UIN Walisongo, 2017), 37-40, http://eprints.walisongo.ac.id/7996/1/132611049.pdf.

${ }^{42}$ Muhammad Chanif, "Analisis Hisab Awal Bulan Qamariah Dalam Kitab Kasyf al-Jilbab” (Skripsi, Semarang, IAIN Walisongo, 2012), 51-55, http://eprints.walisongo.ac.id/1380/.

${ }^{43}$ The author has not found his biography.
} 
From those 51 authors, there are 99 works, in Arabic, Malay and Indonesian, perhaps even Javanese. It is possible that this number will increase with the muftis and the name of the books that has yet to be known. If this amazing amount of works can be reconstructed and collected as material for the study and development of Islamic astronomy in the Indonesian archipelago, the benefit will be felt.

\section{C.2. Classification Method}

The method of reckoning in Islamic astronomy is more towards predetermined criteria. There are five criteria for the method of reckoning that have

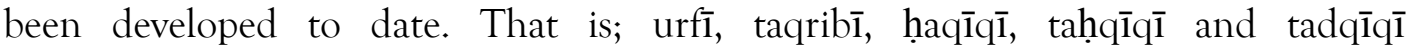
(contemporary). The five methods are the criteria for the method of reckoning which is the treasure trove of astronomy in Indonesia. So that in the determination of the beginning of the month there are sometimes differences. Besides, there are different criteria regarding the time of ijtimā 'and the height of the new moon after ijtimak.

Hisab urfī is still used as a standard in determining the beginning of the month by villagers who do not understand reckoning. Because they are based on the ages of the month which was initiated by Khalīfah 'Umar bin Khațāan. They also stick to the altitude of the hilal on the second and third nights without understanding when the time of ijtimā' occurs. The taqribī method is a method of reckoning that uses the estimation of the position of the sun and moon. So that the results of the reckoning are different from other methods. And one of the characteristics of this taqribī method is that the altitude of the hilal is rather high compared to contemporary methods. The books of astronomy that fall into this category include Sullam al-Nayyirain fī Ma'rifah al-Ijtimā 'wa al-Kusūfain by Muhammad Manșūr bin Abdul Hamīd Betawi, Fath al-Rauf al-Mannān work, Abdul Fatah's Qawāid al-Falakiyyah. , and Muhammad Zubair Abdul Karim's Ittifāq Żāt alBain. $^{44}$

Hisāb haqīīi is the third reckoning criterion whose calculations have used spherical trigonometric rules. The data in this method uses the actual astronomical data of the sun and moon. So, the accuracy is higher than taqribī. The works of

\footnotetext{
${ }^{44}$ Hosen, "Kilas Balik Kalender Hijriyah Indonesia; Perjalanan Menuju Penyatuan Kalender Nasional," Islamuna: Jurnal Studi Islam 4, no. 1 (2017): 92-93, http://dx.doi.org/10.19105/islamuna.v4i1.1352.
} 
musfti of Islamic astronomy categorized as the ḥaqīqī method include Tażkirah alIkhwān by AhmadDahlan Semarang, Ḥisāb Urfī and Hakiki by Muhammad Wardan Yogyakarta, Khulāṣah al-Wafiyyah fī al-Falak bi Jadwāl al-Lughāritmiyyahkarangan and Nubair al-Jailāritmiyyahkarangan M vomit al-Aqwāl fī Ma'rifah Ḥisāb al-Sinīn wa al-Hilāl wa al-Khusūf wa al-Kusūf 'Alā al-Haqūì̄ bi al-Taḥqīqī bi al-Raṣd al-Jadīd by KH.Noor Ahmad Șadiq Suryani Jepara. ${ }^{45}$

While the fourth classification is hisāb tahquīq $\overline{1}$. This method uses astronomical data from the sun and moon based on the results of research or investigation by experts. Besides this method using spherical trigonometry, it also uses more rigorous and detailed corrections, such as interpolation, lower horizon and parallax. The works of earlier mufti that belong into this category are Badi'ah alMis̄āl fịHisāb al-Sinīn wa al-Hilāl by KH. Muhammad Ma'ṣum bin 'Alī alMaskumambangi Jombang. ${ }^{46}$

The last is the contemporary method. This method is included in the category of high accuracy algorithm because the calculation system is more sophisticated than other methods. This means that this calculation method is integrated with today's computer systems. ${ }^{47}$ The works of earlier muftis in this field of Islamic astronomy have yet included into this category. Unless reconstructed in a way of entering numbers and formulas into a computer system, for example excel program.

The methods that the authors mentioned above are methods that still exist today and are used by Indonesians from various cultures and different social statuses. As a result, in Indonesia there has not been an agreement on the use of the national hijriyah calendar.

\section{C.3. Reconstruction of Works and Methods}

Reconstruction in the Kamus Besar Bahasa Indonesia has a meaning; (1) return to normal, and (2) reconstructing (depicting). ${ }^{48}$ Related to the work of earlier

\footnotetext{
${ }^{45}$ Hosen, 93.

${ }^{46}$ Hosen, 93-94.

${ }^{47}$ Hosen, 94.

${ }^{48}$ Rekontsruksi," in Kamus Besar Bahasa Indonesia (Daring/Online), March 10, 2020, https://kbbi.web.id/rekonstruksi.
} 
muftis in the field of Islamic astronomy, it is necessary to rearrange the texts that have "almost" disappeared or are still in the form of manuscripts. In my opinion, the reconstruction of the works of the earlier mufti of Indonesian archipelago is very important. Given that the science of islamic astronomy is one of the most important scientific study field in Islam. Because the science of astronomy developed in Islam is related to problems of worship. Such as the direction of the Qibla, prayer times, the beginning of the moon and the eclipse of the sun and moon.

Besides the factors above, the importance of carrying out the intended reconstruction is a form of appreciation for the efforts of earlier mufti who have dedicated themselves in the study and development of Islamic astronomy. It is undeniable that the science of islamic astronomy that is being enjoyed at this time is due to the skilled hands of the muftis. In the present era and in the future, of course, an approach to the study and development of Islamic astronomy is needed to be adjusted to the respective era. Because the conditions of the upcoming era are of course very different from today's times. Especially when compared to the era of the earlier muftis.

This present and the upcoming times is an era with many technology. Thus, everything that humans need is always integrated with technology. No exception to Islamic astronomy. Therefore, the reconstruction of the work of previous scholars must be carried out by the institutions that are intensely conducting studies and observations in the field of Islamic astronomy. This is in order to increase the spirit of higher education which is known to have a high work ethic. Because the achievements that had been produced by the earlier muftis could not be separated from the high work ethic as Islamic astronomical scientists at that time. ${ }^{49}$

In order to carrying out the reconstruction of the work, at least two things need to be through, that are;

First; the Reconstruction of the work. Based on the writer's search for the works of earlier muftis through limited literary books, 87 works is produced with various titles. Of the many titles, there are still manuscripts that have not been published.

${ }^{49}$ Arwin Juli Rakhmadi Butar-Butar, Khazanah Astronomi Islam Abad Pertengahan, 1st ed. (Purwokerto: UM Purwokerto Press, 2016), 9. 
Some of them are the original writings of the author. And some of the others are already in manuscript. The search results do not necessarily exist. It could also be in the form of information that someone has written a particular book. But physically is not there.

It is necessary to conduct a search of these works, both those that have been mentioned above or not. This was done in order to collect data on the works of the Indonesian archipelago's earlier muftis of Islamic astronomy. This includes on finding out physical evidence of the work, whether in the form of manuscripts, handwritten or printed ones. This search needs to be carried out jointly between universities. Or done by lecturers who are directly related to astronomy. For example the Indonesian Falak Lecturer Association (ADFI) by forming a team. This will provide accurate data regarding the title and number of search results for the work.

After the search is completed, the next step is to reprint the work that has already been printed. Or rewrite it for a work that is still in manuscript form. By doing these two things (tracing and reprinting), the scholar's work can be reviewed and can be used as material for further research.

Second; Reconstruction Method. The reconstruction of the work as the writer described above is a concrete step towards appreciation for the authors who have contributed to writing books of science of Islamic astronomy. It is hoped that with the reconstruction, there will be a re-existence of these "almost" lost works. As the proverb says, "A great nation is a nation that appreciates the services of its heroes". Likewise with this field of astronomy. "The generation that has advanced in the development of Islamic astronomy is a generation that is proud and appreciates the works of its predecessors".

Appreciating the works of his predecessors, among others, by reviewing books / books he has written. Then conduct a review and reconstruction of the methods used in writing, so that it becomes a books that will be suited in accordance with the development of science and technology. This means that by reconstructing the method, it will increase the level or grade from the criteria of taqribī to tahqī $q \overline{1}$ for example. Because in the writer's opinion, the mutaakhkhirin (current) experts of 
Islamic astronomy in producing his works, are limited to making derivations from previous works by making a few modifications in the developed formulas.

It is necessary to pay attention in reconstructing the methods of the work of earlier muftis, so that their characteristics do not disappear immediately, that are; (1) continue to display / accomodate the tables that become references in the work, and (2) reconstruct the calculation formulas adapted to the trigonometric algorithm. As such, the original work of the authors has been preserved. Even with a different face. For example, replacing burūj values with degrees to make it easier for beginners to learn. Because the average sun and moon data in the works of earlier muftis used a burūj which had a value of 30 degrees. Like a burūj 1 degree 6 to 36 degrees. Burūj 10 degrees 17 becomes 317 degrees, and so on. This is taken for none other than to facilitate calculations when doing interpolation (ta'dīl) as the author did with the reconstruction of the book Badī'ah al-Mis̄āl. ${ }^{50}$

\section{Conclusion}

From the above explanation it can be concluded that, first; By tracing the works of previous Indonesian scholars, it will be clearly known, how many works have been produced in the field of Islamic astronomy in each region. This shows that the earlier muftis of Indonesian archipelago had high attention and dedication to the development of Islamic astronomy at that time. Second; By doing the classification method, it will be found a comparison of the number of works including the taqribī and taḥī $\mathbf{1} \overline{1}$ categories. Third; By reconstructing the work of the taqribī category into the tahqīq $\overline{1}$ category, it is increasingly fostering the enthusiasm to carry out scientific studies that are very useful in order to increase insight and knowledge in the present and in the future. And fourth; by republishing the scholar's work, it will preserve the scientific treasures of science which can be used as a reference for future research.

\section{E. Bibliography}

Abdullah, Wan Mohd. Shaghir. "Kyai Muhammad Shalih al-Fathani - Ahli Falak Nusantara." Ulama Nusantara (blog). Accessed June 14, 2020. http://ulamanusantara.blogspot.com/2006/11/kiyai-muhammad-shalih-al-fathani-ahli.html.

\footnotetext{
${ }^{50}$ Hosen, Nadir; Ikhtishar Badî'ah al-Mitsāl karya KH. Ma'shum bin 'Ali (Pamekasan: Duta Media, 2018).
} 
Afriansyah, Rejal. "Biografi Tengku Haji Muhammad Ali Irsyad (Abu Teupin Raya 19152003).” Skripsi, Universitas Syiah $\quad 2017$. https://etd.unsyiah.ac.id/baca/index.php?id=47073\&page=10.

Amin, M. Faishol. "Studi Analisis Pembaruan Perhitungan Awal Bulan Kamariah Dalam Kitab Ittifaq Dzatil Bain Karya KH. Moh. Zubair Abdul Karim.” Skripsi, UIN Walisongo, 2016. http://eprints.walisongo.ac.id/5770/1/122111071.pdf.

Ardi, Unggul Suryo. "Studi Analisis Hisab Awal Bulan Kamariah Dalam Kitab Wasilatu AlMubtadi'in Fi Tarjamati Risalati Al-Qamarain Fi Ijtima'i Al-Nayyirain Karya Syekh Muhammad Nawawi Yunus.” Skripsi, UIN Walisongo, 2017. http://eprints.walisongo.ac.id/7996/1/132611049.pdf.

Arifin, Moch., and Moh. Asif. "Penafsiran al-Qur’ān KH. Iḥsān Jampes; Studi Intertekstualitas Dalam Kitab Sirāj al-Ṭālibīn.” Al-Itqan; Jurnal Studi al-Qur`an 1, no. 2 (July 2015). https://www.academia.edu/39944231/PENAFSIRAN_AL_QURAN_KH_IHSAN_ JAMPES_Moh_Arifin20190727_18551_vbia9k.

Azhari, H. Susiknan. Ensiklopedi Hisab Rukyat. 3rd ed. Yogyakarta: Pustaka Pelajar, 2012.

Azra, Azyumardi. Jaringan Ulama Timur Tengah $\mathcal{E}$ Kepulauan Nusantara Abad XVII $\mathcal{E}$ XVIII; Akar Pembaharuan Islam di Indonesia. Perenial. Depok: Prenadamedia Group, 2018.

BN, Utsman. "Biografi KH. A. Ghazaly Ahli Hisab Persatuan Islam." Blognya Orang Islam (blog). Accessed January 28, 2019. https://muslimnurdin.wordpress.com/2010/10/23/biografi-kh-a-ghazaly-ahli-hisabpersatuan-islam/.

Butar-Butar, Arwin Juli Rakhmadi. "Kajian Ilmu Falak Di Indonesia: Kontribusi Syekh Hasan Maksum Dalam Bidang Ilmu Falak." Journal of Contemporary Islam and Muslim Societies 1, no. 1 (June 2017): 113-34.

- Khazanah Astronomi Islam Abad Pertengahan. 1st ed. Purwokerto: UM Purwokerto Press, 2016.

Butar-Butar, H. Arwin Juli Rakhmadi. Mengenal Karya-Karya Ilmu Falak Nusantara; Transmisi, Anotasi, Biografi. I. Yogyakarta: LKiS, 2017.

Chamami, M. Rikza. "KH. Ahmad Dahlan: Ahli Falak Nusantara." NU Online, Agustus 2016. https://www.nu.or.id/post/read/70710/kh-ahmad-dahlanahli-falak-nusantara.

Chanif, Muhammad. "Analisis Hisab Awal Bulan Qamariah Dalam Kitab Kasyf al-Jilbab." Skripsi, IAIN Walisongo, 2012. http://eprints.walisongo.ac.id/1380/.

Hassan, Che Ku Nur Saliehah binti Che Ku. "Sheikh Ahmad Fatani \& His Contribution in (Fiqh) Islamic Jurisprudence Writing." International Journal of Academic Rersearch in Bussiness and Social Sciences 7, no. 4 (2017): 186-93.

Hidayat, R. Arid. "Kontroversi Hukum Rokok Dalam Kitab Irsyād al-Ikhwān Karya Syeikh Iḥsān Muhammad Daḥlān.” International Journal Ihya`Ulum Al-Din 17, no. 2 (2015): 189-208.

Hidayatullah, Nur. "Jaringan Ulama Falak Nusantara (Studi Geonologi Keilmuan Falak Syekh Muhammad Yasin Al-Fadani).” Al-Afaq; Jurnal Ilmu Falak dan Astronomi 1, no. 1 (2019): 35-66.

Hosen. "Kilas Balik Kalender Hijriyah Indonesia; Perjalanan Menuju Penyatuan Kalender Nasional." Islamuna: Jurnal Studi Islam 4, no. 1 (2017): 81-111. http://dx.doi.org/10.19105/islamuna.v4i1.1352. 
—. Nadir; Ikhtishar Badî'ah al-Mitsāl karya KH. Ma'shum bin 'Ali. Pamekasan: Duta Media, 2018.

Humaidi. "Guru Merah Putih: Ulama Betawi Dalam Dalam Perjuangan Kemerdekaan (1945-1950)." Makalah presented at the Seminar Nasional Sejarah ke 4 Jurusan Pendidikan Sejarah Universitas Negeri Padang, Padang. Accessed June 11, 2020. https://osf.io/hfkdy/download/?format=pdf.

Husnan, Usman, Moch. Muhairil Yusuf, and Badrus Sholeh. Guru Orang-Orang Pesantren. Edited by Mohammad Achyat Ahmad. 1st ed. Pasuruan: Pustaka Sidogiri, 2013.

Ilyas, Ahmad Fauzi. "Syekh Ahmad Khatib Minangkabau dan Polemik Tarerkat Naqsyabandiyah di Nusantara." Journal of Contemporary Islam and Muslim Societies 1, no. 1 (2017): 86-112. http://dx.doi.org/10.30821/jcims.v1i1.1008.

Izzuddin, Ahmad. "Syaikh Zubair Umar al-Jailany (w. 1411 H/1990 M) dalam Sejarah Hisab di Indonesia." Al-Marshad; Jurnal Astronomi Islam dan Ilmu-Ilmu Berkaitan 2, no. 2 (2016): 94-105. https://doi.org/10.30596/jam.v2i2.2532.

Khazin, Muhyiddin. Kamus Ilmu Falak. Yogyakarta: Buana Pustaka, 2005.

M., Toni. "Karakteristik Pembaharuan Pemikian Islam oleh Syeikh Djamil Djambek (1863. 1947) dan Syeikh Abdul Karim Amrullah (1879-1945) di Minangkabau pada Awal Abad XX.” Skripsi, UIN Sunan Kalijaga, 2008. http://digilib.uin-suka.ac.id/2306/.

Mahiroh, Faridah Hidayatul. "Perbandingan Pemikiran KH. Muhammad Faqih Maskumambang dan KH. Ammar Faqih Maskumambang Dalam Merespon Gerakan Wahabi Tahun 1922-1961 M.” Skripsi, UIN Sunan Ampel, 2019. http://digilib.uinsby.ac.id/31737/.

Mustofa, Ali. Tashilul Wildan; Terjemah Sullamun Nayyiroin. 1st ed. Ploso: Maktabah Musthofafwiyah, 2018.

Noupal, Muhammad. "Kontroversi Tentang Sayyid Utsman bin Yahya (1822-1914) Sebagai Penasehat Snouck Hurgronje." In Annual International Conference on Islamic Studies (AICIS XII), 1370-91. Surabaya: UIN Sunan Ampel, 2012. https://core.ac.uk/download/pdf/34212359.pdf.

Putri, Hasna Tuddar. "Pemikiran Syekh Abbas Kutakarang tentang Hisab Penentuan Awal Bulan Hijriyah,” n.d. http://eprints.walisongo.ac.id/41/1/Hasna_Tuddar_Putri_Tesis_Sinopsis.pdf.

"Rekontsruksi." In Kamus Besar Bahasa Indonesia (Daring/Online), March 10, 2020. https://kbbi.web.id/rekonstruksi.

Rizal, Muhammad, and Muhammad Iqbal. "Dayah and Meunasah: Abu Teupin Raya Is the Reformer of Islamic Education in Aceh." Jurnal Pendidikan Islam 7, no. 1 (June 2018): 185-208. https://doi.org/10.14421/jpi.2018.71.185-207.

Rohmat, H. "Penentuan Awal Bulan Qamariyah Menurut Muhammadiyah." Ijtimaiyya; Jurnal Pengembangan Masyarakat 7, no. 1 (February 2014): 127-45.

Rosyadi, Mohammad Imron. "Pemikiran Hadis Abdurrauf As-Singkili Dalam Kitab Mawa'izat Al-Badi'ah.” Diroyah; Jurnal Ilmu Hadis 2, no. 1 (September 2016): 55-62.

Rozali, Muhammad. "Kontribusi Syaikh Hasan Maksum dalam Bidang Pendidikan di Sumatera Utara." JUSPI: Jurnal Sejarah Peradaban Islam 1, no. 2 (2017): 277-87.

Saad, Diyak Ulrahman bin Mat, and Muhammad Faiz Mukmin bin Abdul Mutalib. "Sumbangan Shaykh Ahmad Al-Fathani (1856-1908) Terhadap Ilmu Nahu," n.d. http://conference.kuis.edu.my/pantumn2017/images/prosiding/Diyak.pdf. 
Sa'adah, Arifatus. "Ngudud dan Ngipok Menurut Syaikh Ihsan Muhammad Dahlan alJampesi Kediri.” Skripsi, UIN Sunan Ampel, 2016. http://digilib.uinsby.ac.id/4734/.

SW, Oman Fathurohman. "Saadoe'ddin Djambek Dan Hisab Awal Bulannya." In Bunga Rampai Hisab Rukyat dan Perbedaannya, 92-123. Jakarta: Departemen Agama RI, 2018. http://digilib.uin-suka.ac.id/id/eprint/29754.

Sya'ban, A. Ginanjar. "Sirajut Thalibin, Syarah Kiai Ihsan Jampes atas Kitab Tasawuf Imam al-Ghazali.” NU Online, April 2017. https://www.nu.or.id/post/read/76762/sirajut-thalibin-syarah-kiai-ihsan-jampes-ataskitab-tasawuf-imam-al-ghazali. 